\title{
MINERAL ELEMENT CONTENT OF ORGANICALLY VERSUS CONVENTIONALLY GROWN STRAWBERRIES
}

\author{
Virág Mihálka ${ }^{1^{*}}$, Attila Hüvely ${ }^{1}$, Judit Pető ${ }^{1}$ and Ildikó Király ${ }^{2}$ \\ ${ }^{1}$ Department of Agriculture, Faculty of Horticulture and Rural Development, \\ John von Neumann University, Hungary \\ 2 Department of Horticulture, Faculty of Horticulture and Rural Development, \\ John von Neumann University, Hungary \\ https://doi.org/10.47833/2020.2.AGR.041
}

\section{Keywords: \\ Organic farming \\ Fragaria $\mathrm{x}$ ananassa \\ Mineral elements \\ Functional food \\ Health-promoting effect}

\section{Article history:}

Received 10 May 2020

Revised 20 May 2020

Accepted 25 May 2020

\begin{abstract}
It is generally believed, that organically -grown fruits are more nutritious. In the present work the the macro- and microelement composition of organically versus conventionally -grown strawberries were compared. Besides this, the effect of a bacterial soil inoculant and an algae based biostimulant was tested. Based on the available data it can not be proved, that organically -grown fruits had higher mineral content.
\end{abstract}

\section{Introduction}

The source of mineral elements of our body is the consumed food. The consumption of appropriate amounts of microelements should be highlighted. Among the minder elements micronutrients are more likely to get into the body in low amounts, and can cause deficiency symptoms. Adequate amounts of micronutrients are essential for maintaining our health. Fruits are important sources of mineral elements. Mineral content of the fruit depends on many different factors like the quality of soil, quantity and quality of the nutrients applied, variety, growing conditions, weather conditions etc.

Strawberry is considered to be a functional food [1]. The health-promoting properties of strawberries are due to the synergistic effect of its constituents (minerals, sugars, organic acids, antioxidants, fibers, etc.), which can be strongly influenced by the growing conditions. In terms of mineral elements, strawberries are a well-known source of $\mathrm{K}, \mathrm{P}, \mathrm{Mg}$, Ca etc.

It is widely believed that organic fruits are safer, healthier, and more nutritious. Many researches have proved that organic fruits contain less (or no) pesticide residues [2], [4], [8], but there is still no evidence, that organically -grown fruits would be more nutritious.

There are numerous reports compare the macro- and microelement content of organically and conventionally- grown fruits, but the results are contradictory. In our opinion, one of the reasons for the contradictory results could be that organic, conventional and integrated areas are located in different areas. Therefore, soil parameters and climatic factors (rainfall, hours of sunshine etc.) can be different, and it is difficult to separate the effect of the many complex and interacting factors.

Recognizing this problem, we set up an experiment in which organic and inorganic fertilizers were applied on adjacent plots on the same area. Application of this experimental setup helps to eliminate the variance coming from the different climate conditions and soil properties.

Natural-based biostimulants have become more and more popular in organic farming [5], and are gaining increasing market share in the market for agricultural nutrients and pesticides. In view of the increasing importance of biostimulants in organic farming, we examined the effect of a bacterial soil inoculant and an algae-based biostimulant authorized in organic farming and widely used in

\footnotetext{
* Corresponding author. Tel.: +36 76 517696;

E-mail address: mihalka.virag@kvk.uni-neumann.hu
} 
Hungary. A well-known effect of PGPR bacteria is helping plants in the uptake of certain mineral elements from soil (for review see [9]). The algae-based biostimulant was included in the experiment because, according to the manufacturer's recommendation, hormones, amino acids and fatty acids produced by the algae cells get into the plant leaves and help to prevent stress effects, and might improve micronutrient supply.

In our previous article antioxidant and polifenol capacity of organically and conventionallygrown strawberry were compared [10]. In the present work macro- and microelement content of conventional and organic strawberry are studied. Besides this, in case of organic plants effect of soil inoculation and biostimulant treatments on the mineral element content of strawberry were tested as well.

\section{Material and Methods}

\subsection{Experimental set up, cultivar, planting, culture conditions}

Our experiment was set up in the Experimental Garden of John von Neumann University, Kecskemét (46 $\left.{ }^{\circ} 54^{\prime} \mathrm{N} ; 19^{\circ} 40^{\prime} \mathrm{E}\right)$ in Hungary, according to Figure 1.

Frigo transplants (Fragaria $\mathrm{x}$ ananassa 'Asia) were planted on the $26^{\text {th }}$ of March 2019 with a planting density of $60+30^{\star} 25 \mathrm{~cm}$, in tween-rows. 4 tween rows were planted plus $1-1$ single rows on both sides.

Different nutrient supply methods were applied, as shown on Figure 1. The different plots were separated by fallow areas (Fig. 1.). Nutrient supply was planned based on the results of soil analysis, so that both organic and conventional plots got the same amount of potassium and sodium. $233 \mathrm{~kg}$ / ha of Haifa Turbo and $125 \mathrm{~kg} /$ ha of granular potassium sulphate was applied to the conventional plot (marked CONV). $700 \mathrm{~kg} / \mathrm{ha}$ of Phoenix pelleted poultry manure was applied to the organic area. Irrigation was performed with a microspray irrigation system. On the organic plot culture practices (fertilization, irrigation, weed control) were performed according to the national and EU regulations of organic farming.

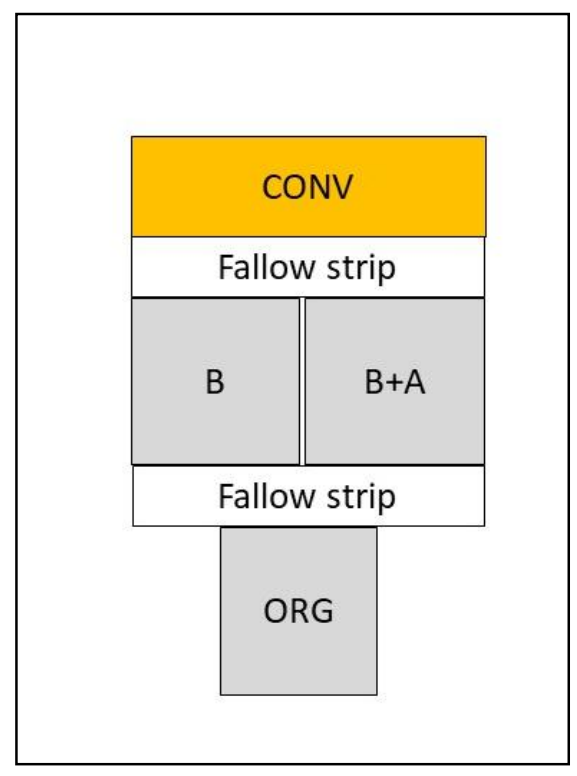

Figure 1. Experimental design. $8 m^{*} 4 m$ with $0.5 m$ fallow strips. CONV: Nutrient supply according to conventional farming methods ORG: Nutrient supply according to the regulations for organic farming B: Organic farming+ BactoFil B-10 treatment B+A: Organic farming + BactoFil B10 and Algafix treatments

Due to several weeks of rain in early May, fungal control became necessary. On the $31^{\text {th }}$ of May 2019, copper-containing Scudo foliar fertilizer preparation approved in organic farming was applied at a concentration of $2 \mathrm{ml} / \mathrm{l}$. 


\subsection{Bacterial inoculations}

On one plot (marked with B on figure 1.) a bacterial soil inoculant (BactoFil B-10) was applied. The product was diluted with tap water, sprayed on the soil and worked in immediately. Inoculation was executed directly before planting. Besides, $100 \mathrm{ml}$ of $5000 \times$ diluted BactoFil B-10 was poured in every planting hole, right before planting of frigo transplants.

\subsection{Treatment with alga suspension}

A microbial product (Algafix), containing Scenedesmus obtusiusculus cells was diluted with tap water and sprayed on the plants in $2 \mathrm{l} /$ ha quantity at the beginning of flowering.

\subsection{Determination of fruit macro - and microelement content}

About 500-500 g of fresh fruits per treatment were collected with random sampling the $4^{\text {th }}$ of June 2019. In order to avoid border effect samples were not taken from the single rows planted on the side of plots.

Calyces were removed, and then fruits were thoroughly washed, and comminuted. Air-dry samples $\left(70{ }^{\circ} \mathrm{C}\right)$ were thoroughly minced. Dry matter was measured gravimetrically. For elemental studies powdered samples were digested in a microwave device by means of concentrated nitric acid and hydrogen peroxide (Milestone Ethos Plus). Main macro element content was measured by optical emission spectrometer (ICP-AES method). Nitrogen content in leaf blades was determined using the Kjeldahl method [6] after sulphuric acid digestion (FOSS Kjeltec 2300). Macro element (N, $\mathrm{P}, \mathrm{K}, \mathrm{Ca}, \mathrm{Mg}$ ) contents were calculated in $\mathrm{g} / 100 \mathrm{~g}$ dry matter, whereas micro-element $(\mathrm{Mn}, \mathrm{Zn}, \mathrm{Cu}$, $\mathrm{B}, \mathrm{Mo})$ contents were given in $\mathrm{mg} / \mathrm{kg}$ dry matter.

\subsection{Leaf analysis}

50-50 leaves (collected from 20-20 randomly selected plants) per treatment were collected, on the $18^{\text {th }}$ of September 2019. In order to avoid border effect, samples were not taken from the single rows planted on the side of plots. Newly developed laves were selected. Petioles of leaves were removed, and then leaf blade samples were washed. Drying was carried out at $70^{\circ} \mathrm{C}$, then airdry samples were minced. Dry matter was measured gravimetrically. Concentrations of main macroand microelements were determined as described in 2.4. Macro element ( $N, P, K, C a, M g)$ contents were calculated in $\mathrm{g} / 100 \mathrm{~g}$ dry matter, whereas micro-element $(\mathrm{Mn}, \mathrm{Zn}, \mathrm{Cu}, \mathrm{B}, \mathrm{Mo})$ concentrations were given in $\mathrm{mg} / \mathrm{kg}$ dry matter.

\section{Results and Discussion}

\subsection{Macro- and microelement concentrations of leaves}

Differences in the mineral element content of freshly developing leaves in the case of different treatments were measured. The aim was to get information about the effect of different nutrient supply and microbial products, and to have information for planning the nutrient supply for the following year. Differences in mineral element concentrations of leaf samples are shown on Figure 2 and 3. We compared the results of our measurements with literature data.

Reganold et al. (2013) analyzed data from 13 organical and conventional farms [11]. Regarding the macroelements, they found significantly higher $\mathrm{P}$ and $\mathrm{Mg}$ levels of conventionally produced strawberry leaves. For other elements examined (N, Ca, K), no significant differences were found between organic and conventional strawberry leaves. Similarly to Reganold et al. (2013), we found that leaves collected from conventionally grown plants contained higher amounts of $\mathrm{P}$ and $\mathrm{Mg}$ (Fig. 2). However, for the other elements, we also obtained higher values on the conventional plot, except for K, where organically -grown plants showed higher concentrations. The use of a bacterial soil inoculant resulted in an increase for most elements, however, it is difficult to interpret that combined use of BactoFil and Algafix resulted lower concentrations for several trace elements (Fig. 2). 


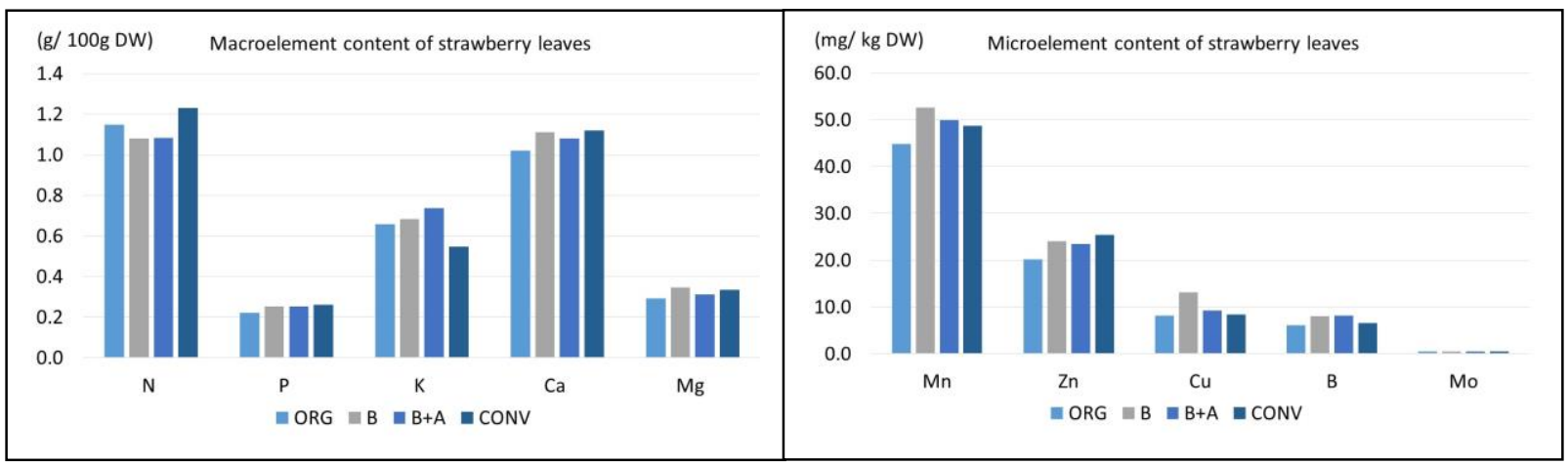

Figure 2. Average mineral element concentrations of strawberry leaves grown organically versus conventionally. The different treatments marked as: ORG: nutrient supply according to organic

farming B: organic farming + BactoFil B-10 treatment $B+A$ : organic farming + BactoFil $B-10$ and Algafix treatments, CONV: conventional

Of course, since this is a one-off measurement, we cannot draw far-reaching conclusions from the data obtained. Due to conflicting results, it is recommended to repeat the study.

\subsection{Macro- and microelement concentrations of fruits}

From nutrition physiology, point of view, the composition of the fruit what is important, which does not always correlate with the element composition of the leaves.

When mineral element content of fruits were measured we found that $\mathrm{N}$ concentrations are significantly lower in the organic fruits (Fig. 3). Among the microelements $\mathrm{Mn}$ concentration seems to be lower in organic fruits, at the same time combned application of BactoFil and Algafix resulted the increase of Mn concentration.

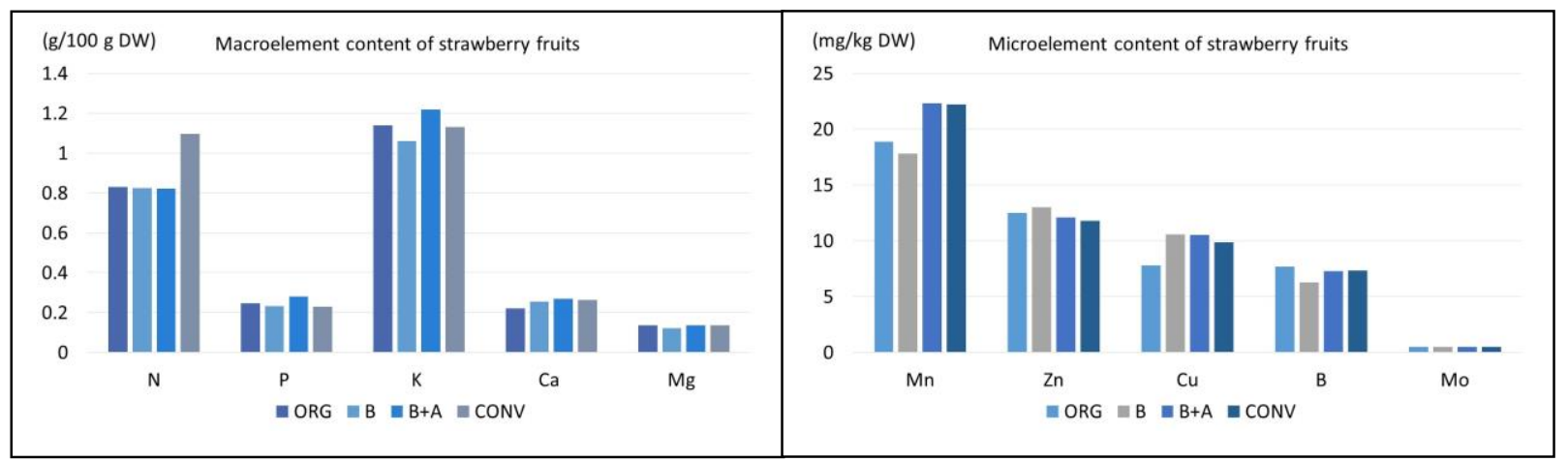

Figure 3. Average mineral element concentrations of organically versus conventionally grown strawberry fruits.

The different treatments marked as: ORG: nutrient supply according to organic farming $B$ : organic farming+ BactoFil B-10 treatment B+A: organic farming+BactoFil B-10 and Algafix treatments CONV: conventional

In the literature, we find contradictory data on whether we find a significant difference in the nutritional parameters of fruits produced in organic and conventional farming. Collecting literature data, we find quite a variety in terms of mineral element content. To be able to compare the different literature data with each other and with our own measurement results, we converted all data to mg / $100 \mathrm{~g}$ fresh weight and summarized them in Table 1 and 2. In this way, we can get information about the amount of mineral elements we consuming per one $\mathrm{kg}$ of fresh fruit. In the comparison the data of general nutritional values of strawberries (Bíró, Basu in Table 1. and 2) and the data of two articles 
containing specific measurement results, with the differences between organic, conventional and integrated cultivations (Reganold, Kristl in Table 1. and 2) were examined.

Comparing 13 organic and conventional strawberry growing farms, Reganold and coworkers concluded that $\mathrm{N}$ was significantly higher in conventional fruits than the other elements, while the differences found were not significant for the other elements [11]. However, as the dry matter content of the fruits is higher in the case of organic fruits, the $\mathrm{N}$ concentration calculated on the fresh weight is just showing the opposite of the above results (Table 1.)

Table 1. Comparison of dry matter content and macroelement concentrations of strawberry fruits ( $\mathrm{mg} / 100 \mathrm{~g}$ FW) based on literature data and own experiment.

\begin{tabular}{|c|c|c|c|c|c|c|c|}
\hline & \multirow{2}{*}{$\begin{array}{c}\text { Dry } \\
\text { weight } \\
(g / 100 g)\end{array}$} & $N$ & $P$ & $K$ & $\mathrm{Ca}$ & $M g$ & \multirow[b]{2}{*}{ Data source } \\
\hline & & \multicolumn{5}{|c|}{$\mathrm{mg} / 100 \mathrm{~g} \mathrm{FW}$} & \\
\hline$O R G$ & 9.1 & 75.5 & 22.5 & 103.9 & 20.2 & 12.3 & own results \\
\hline$B$ & 8.7 & 72.0 & 20.1 & 92.3 & 22.3 & 10.6 & own results \\
\hline$B A$ & 8.8 & 72.1 & 24.7 & 107.2 & 23.6 & 11.9 & own results \\
\hline CONV & 9.5 & 104.2 & 21.9 & 107.4 & 25.1 & 12.8 & own results \\
\hline Bíró & & & & 145.0 & 28.1 & 18.0 & {$[3]$} \\
\hline Basu & & & 13.0 & 148.0 & 16.0 & 11.0 & [1] \\
\hline Reganold ORG & 10.3 & 105.1 & 25.4 & 154.5 & 12.4 & 13.4 & [11] \\
\hline Reganold CONV & 9.3 & 100.0 & 26.5 & 152.8 & 12.2 & 12.4 & [11] \\
\hline Kristl ORGANIC & & & 22.5 & 110.8 & & 9.7 & [7] \\
\hline $\begin{array}{l}\text { Kristl } \\
\text { INTEGRATED }\end{array}$ & & & 26.2 & 152.1 & & 11.9 & [7] \\
\hline
\end{tabular}

Kristl and coworkers (2013) compared 5 different strawberry varieties in organic and integrated cultivation. Differences in mineral element contents due to cultivation technology proved to be smaller than differences between varieties. However, they found that the $\mathrm{Cu}$ content of organic strawberries was significantly higher, while for several other elements $(\mathrm{K}, \mathrm{Mg}, \mathrm{P}, \mathrm{Fe}, \mathrm{Zn})$ they showed lower concentrations (Table 1. 2.)

Table 2. Comparison of microelement concentrations of strawberry fruits ( $\mathrm{mg} / 100 \mathrm{~g}$ FW) based on literature data and own experiment

\begin{tabular}{|c|c|c|c|c|c|c|}
\hline & $\mathrm{Fe}$ & $M n$ & $Z n$ & $\mathrm{Cu}$ & $B$ & \multirow[b]{2}{*}{ Data source } \\
\hline & \multicolumn{5}{|c|}{$\mathrm{mg} / 100 \mathrm{~g} \mathrm{FW}$} & \\
\hline$O R G$ & 0.226 & 0.157 & 0.104 & 0.064 & 0.0640 & own results \\
\hline$B$ & 0.157 & 0.135 & 0.099 & 0.080 & 0.0476 & own results \\
\hline$B A$ & 0.150 & 0.172 & 0.093 & 0.081 & 0.0563 & own results \\
\hline CONV & 0.244 & 0.201 & 0.107 & 0.089 & 0.0661 & own results \\
\hline Bíró & 0.300 & 0.136 & 0.063 & 0.029 & & [3] \\
\hline Basu & 0.750 & & & 0.049 & & [1] \\
\hline Reganold ORG & & & 0.108 & & 0.1494 & [11] \\
\hline Reganold CONV & & & 0.092 & & 0.1408 & [11] \\
\hline Kristl ORGANIC & 0.219 & 0.128 & 0.099 & 0.036 & & [7] \\
\hline Kristl INTEGRATED & 0.510 & 0.211 & 0.119 & 0.029 & & [7] \\
\hline
\end{tabular}

It should be noted that each farm is located a different location, so that in addition to the different cultivation methods and nutrient replenishment, there may also be differences in the soil 
and local weather parameters of each area and it is very difficult to separate the effects of the different factors.

We would highlight some observations, comparing our own results with the literature data. One of these is that the amount of $\mathrm{Cu}$ is significantly higher in our fruits than the value expected from the nutrient table, which might be the effect of copper-containing Scudo foliar fertilizer preparation used. The amount of $\mathrm{K}$, on the other hand, lags behind the amount expected based on literature data, suggesting that the supply of $\mathrm{K}$ was not satisfactory. Based on the comparison of the data (Table 1. and 2.), we cannot say for any of the elements that it is present in higher concentrations in organic fruits.

\section{Conclusion}

Although our nutrient replenishment plan was prepared based on soil analysis data, some element concentrations for leaf and fruit proved to be lower the expected based on literature data, e.g. $\mathrm{K}$ concentration remains below expectations, suggesting that we need to use a higher input in the next growing season.

The differences found between the individual treatments are not significant for human micronutrient intake. At the same time, we have to take into account that the concentrations of mineral elements show a positive and negative correlation with each other.

As the mineral content of fruits is developing due to many mutually reinforcing and weakening complex factors ( $\mathrm{pH}$, ion competition, soil microbial activity, genotype, etc.): it is very difficult to separate the effect of each factor and to interpret the data.

The results of our measurements suggest that the consumption of strawberries has a healthprotective effect, it can contribute to the intake of several important micronutrients, but based on the currently available data, it cannot be demonstrated that the microelement content of organic fruits would be higher. At the same time, high levels of health-protecting seconder metabolits, antioxidants, as well as lower amounts of chemical residues, makes consumption of organic fruits preferable from the point of view of human health.

\section{Acknowledgment}

Thank you for the support of the research carried out in the framework of the EFOP-3.6.2-162017-00012 „Developing a functional, healthy and safe food product chain model from field to table in a thematic research network". The project is funded by the Hungarian State and the European Union, co-financed by the European Social Fund, and is part of the Széchenyi 2020 program.

\section{References}

[1] Basu, A., Nguyen, A., Betts, N. M., \& Lyons, T. J. (2014). Strawberry as a functional food: an evidence-based review. Critical reviews in food science and nutrition, 54(6), 790-806. DOI: 10.1080/10408398.2011.608174

[2] Baker BP, Benbrook CM, Groth E, III, Benbrook KL (2002) Pesticide residues in conventional, integrated pest management (IPM)-grown and organic foods:insights from three US data sets. Food Addit Contam 19: 427446. DOI: 10.1080/02652030110113799

[3] Bíró Gy- Lindner K (1999): Táplálkozástan és tápanyag-összetétel. Medicina, Budapest

[4] Curl CL, Fenske RA, Elgethun K (2003) Organophosphorus pesticide exposure of urban and suburban preschool children with organic and conventional diets. Environ Health Persp 111: 377-382. DOI: 10.1289/ehp.5754

[5] De Pascale, S., Rouphael, Y., \& Colla, G. (2017). Plant biostimulants: innovative tool for enhancing plant nutrition in organic farming. Eur. J. Hortic. Sci, 82(6), 277-285. DOI: 10.17660/eJHS.2017/82.6.2

[6] Kjeldahl, J.G.C.T. (1883): Neue methode zur bestimmung des stickstoffs in organischen körpern. Fresenius' Journal of Analytical Chemistry 22(1): 366-382.

[7] Kristl, J., Urbanek, A., Kramberger, B., \& Grobelnik, S. (2013). Strawberries from integrated and organic production: Mineral contents and antioxidant activity. Acta Chimica Slovenica, 60(1), 19-25.

[8] Lu C, Toepel K, Irish R, Fenske RA, Barr DB, Bravo R (2006) Organic diets significantly lower children's dietary exposure to organophosphorus pesticides. Environ Health Persp 114: 260-263. DOI: 10.1289/ehp.8418

[9] Menendez, E., \& Garcia-Fraile, P. (2017). Plant probiotic bacteria: solutions to feed the world. AIMS microbiology, 3(3), 502-524. https://doi.org/10.3934/microbiol.2017.3.502

[10] Mihálka, V., Székelyhidi R., Hanczné Lakatos E., Kapcsándi V., Palkovics A., Király I (2020): Ökológiai és konvencionális körülmények közöett termesztett szamóca (Fragaria $\times$ ananassa) hozama és antioxidáns kapacitása. GRADUS 7:2, 12-17. 
[11] Reganold JP, Andrews PK, Reeve JR, Carpenter-Boggs L, Schadt CW, et al. (2010): Fruit and Soil Quality of Organic and Conventional Strawberry Agroecosystems. PLOS ONE 5(9): 1-14. DOI:

10.1371/journal.pone.0012346 